Omni-Akuatika, 14 (1): 87-95, 2018
ISSN: 1858-3873 print / 2476-9347 online
Research Article
journal homepage: http://ojs.omniakuatika.net

\title{
Distribution and Habitat Characteristics of Shrimp Juvenile in Segara Anakan Lagoon
}

\author{
Sri Endah Purnamaningtyas, Didik Wahju Hendro Tjahjo
}

Balai Riset Pemulihan Sumber daya Ikan, Ministry of Marine Affairs and Fisheries, Indonesia

Corresponding author : endah purnamaningtyas@yahoo.co.id

Received 24 October 2017; Accepted 25 May 2018; Available online 31 May 2018

\begin{abstract}
S
Shrimp as fishery resources that live in Segara Anakan lagoon is known as a high economic species. So the existence and habitat from larvae to adult more suistable with furthermore to maintain the survival of shrimp The purpose of this study is to determine the characteristics of shrimp juvenile habitat in Segara Anakan lagoon. Sampling is done 3 times (June, August and October 2013), with 9 stations Observation station. Shrimp and fish resource data were collected through self-capture experiments using beam trawl fishing equipment. Beam trawling made of iron frame with a width of $1.0 \mathrm{~m}$, height of $0.3 \mathrm{~m}$ and a net length of $2 \mathrm{~m}$. while the jaring is made of webbing material (supernet $\mathrm{d} / 12$ ) and diameter of mesh $10 \mathrm{~mm}$. The fishing gear is pulled at 2 knots for 10 minutes. The results explaining: 1 . Species distribution each station, 2. Number of abundant species each station and than habitat characteristic each station that the abundance of shrimp based on the amount in Segara Anakan lagoon was dominated by Metapenaeus elegans (205-8723 ind./1000 $\mathrm{m}^{2}$ ), whereas the abundance of $M$. ensis, $F$ merguensis, $P$. semisulcatus and $P$. monodon relatively low had the same habitat, ie waters with high fertility and relatively low salinity, relatively high $\mathrm{pH}$. Found in Motean observation station, Muara Dua, Kleces and Majingklak. Harpiosquilla annandalei (0-330 ind/1000 $\left.\mathrm{m}^{2}\right), P$. monodon $\left(0-238 \mathrm{ind} / 1000 \mathrm{~m}^{2}\right)$, and Acetes sp (0.1-5.196 ind/1000 $\left.\mathrm{m}^{2}\right)$ sounded a lot of water habitat that contain BOT and high zooplankton abundance. Thus the shrimp Harpiosquilla annandalei, $P$. monodon, and Acetes $s p$ are found in Tritih observation stations, and are quite commonly found in Kleces observation stations.
\end{abstract}

Keywords: abundance, habitat preferences, juvenile shrimp, Segara anakan Lagoon

\section{Introduction}

Dudley (2000) stated that the wealth of Segara Anakan fishery resources is characterized by an abundance of various unique and potential biota including 60 species of fish, 19 species of shrimp. The types of crustaceans are dominated by White shrimp species (Fenneropenaeus merguiensis), Jerbung shrimp ( $F$. indicus) and Shrimp krosok or fingers (Metapenaeus elegans), and several other important species. Where in the phase of his life has two places in his life cycle that in sea water and brackish water. Penaeid shrimp have a worldwide distribution in tropical and sub-tropical seas, and are the most important biota in estuarine and coastal habitats (de Abreu, Daniela Carvalho, 2017). At least 19 species of 7 genera are reported from the western ocean region (de Freitas, 2011).

Shrimp usually live in relatively shallow waters with sandy bottom and have high turbidity (Fulanda et al., 2011; Munga et al., 2012). In the larval phase the species prefers the estuary of the river and when entering the juvenile phase moves from the estuary to the sea, where they grow until they mature and lay eggs (Anand, et. al. 2014; Kunze, et.al. 2014 ). These environmental variables can cause differences in the composition of penaeid shrimp species (Anand, et. al. 2014).

Pursuant to that matter hence this research aim to know distribution and characteristic of shrimp juvenile habitat at Segara Anakan lagoon by using environment variable. It is necessary to the focusing to distribution of shrimp as the research fisheries 
management strategies the research ensure sustainability.

\section{Materials and Methods}

\section{Data collection method}

This research was conducted in the Segara Anakan lagoon. Data collection is carried out studies using survey methods (stratified sampling method) (Nielsen \& Johnson, 1985). Sampling have done 3 times, that is June, August and October 2013, at 8 stations, that focusing at: (1) Tritih, (2) Donan, (3) Kebon Sayur, (4) Sapuregel, (5) Montean, (6) Menara Dua, (7) Kleces, (8) Manjingklak, and Plawangan (Figure 1).

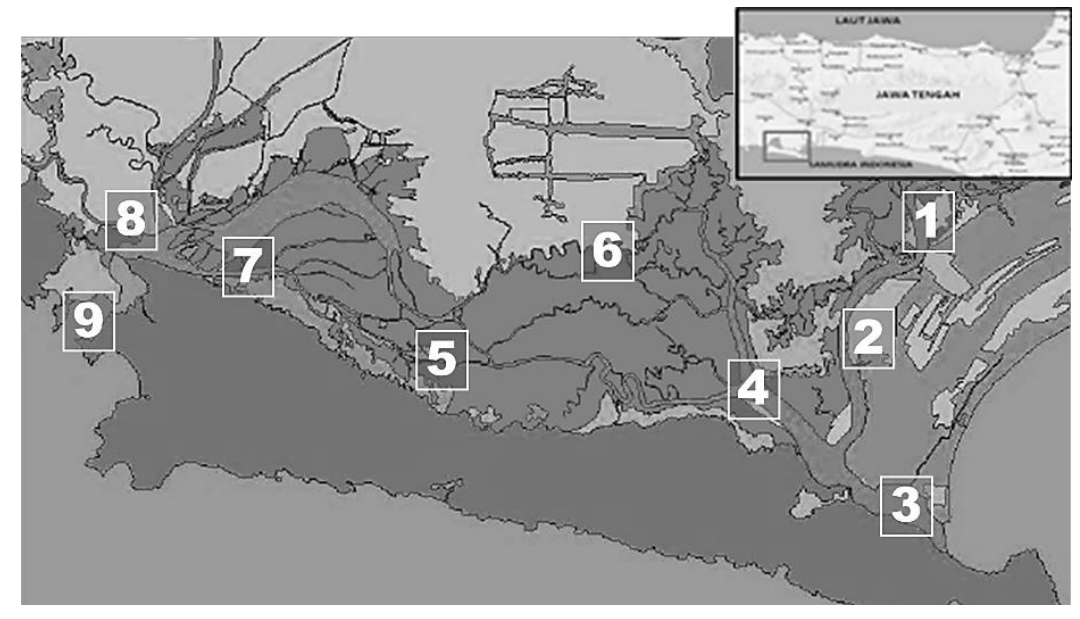

Figure 1. Map of Segara Anakan lagoon (Ardli \& Wolff, 2008) and station sampling observation

\section{Materials and tools}

Some equipment, materials and methods used in the observation of the environmental quality of the lagoon waters are presented in Figure 1. Data of shrimp resource collected throug The materials and methods used in observing the environmental quality of lagoon waters are presented in Table 1. Shrimps were collected of using beam trawl. Beam made of iron with width $1.0 \mathrm{~m}$, height 0.3 $\mathrm{m}$ and net length of $2 \mathrm{~m}$. while the net is made of webbing (supernet $d / 12$ ) and diameter of mesh $10 \mathrm{~mm}$. The fishing gear is pulled at 2 knots for 10 minutes. The position using GPS (Garmin). Water depth is shrimp sampling results were selected and identified and included in plastic bags and preserved in 10\% formalin and labeled.

\section{Data analysis}

Abundance of juvenile shrimp was determined using swept area method, with the formula (modified APHA, 2005):

$$
N=\frac{n \times 1000}{l \times s}
$$

Where: $\mathrm{N}=$ abundance of juvenile shrimp (ind. $/ 1000 \mathrm{~m}^{2}$ ); $\mathrm{n}=$ number of juvenile (Ind.);।
= width of beam trawl $(\mathrm{m}) ; \mathrm{s}=$ length of path covered $(\mathrm{m})$.

The waters quality method proposed by APHA (2005), Davis (1955), and Boyd (1990) (Appendix 1). Phytoplankton by microscope. The calculated based on phytoplankton abundance "Lackey Drop Microtransett Counting" (APHA, 2005) by the formula,

$$
\begin{gathered}
N_{f}=F_{f} * n_{f} \\
F_{f}=\frac{A_{f}}{a_{f} * L_{f}} * \frac{V_{2}}{V_{1}} * \frac{1}{V_{f}}
\end{gathered}
$$

where, $N_{f}=$ abundance of phytoplankton (ind./I), $F_{f}=$ correction factor, $n_{f}=$ number of phytoplankton (ind.), $A_{f}=$ area of glass cover $\left(\mathrm{mm}^{2}\right), a_{f}=$ wide field of view $\left(\mathrm{mm}^{2}\right), L_{f}=$ number of visual field, $V_{1}=$ volume $(\mathrm{ml}), V_{2}=$ volume filtered $(\mathrm{ml})$, dan $V_{f}=$ volume taken (I). with plankton nets, while phytoplankton biomass measurements by taking $500 \mathrm{ml}$ of water sample and $\mathrm{MgCO}_{3}$ to inhibit photosynthesis and stored in dark bottles, chlorophyll content measurements subsequently using "trichromatic". Calculation of chlorophyll a follow equation (APHA, 2005; Stirling, 1985) as calculated based on follows: 
$C_{a}=11,64(O D 663)-2,16(O D 645)+0,10$ (OD630)

where, OD663, OD645 and OD630 = optical density at a wavelength of $663 \mathrm{~nm}, 645 \mathrm{~nm}$ and $630 \mathrm{~nm}$. Furthermore, from the above calculations can be determine chlorophyll content per unit volume $\left(\mathrm{mg} \mathrm{chl} / \mathrm{m}^{3}\right)$ with the following formula :

$$
\begin{aligned}
& \text { Chlorophyll a }\left(\mathrm{mg} \mathrm{chl} / \mathrm{m}^{3}\right)= \\
& \frac{C_{a} * \text { vol. of extract }(\text { liter })}{\text { vol. of water sample }\left(\mathrm{m}^{3}\right)}
\end{aligned}
$$

Variables observed were physicochemical and biological water, such as temperature, depth, water flow, transparancy, texture of the substrate, electrical conductivity, $\mathrm{pH}$, dissolved oxygen, carbon dioxide, alkalinity, organic matter and macrozoobenthos. The data obtained were analyzed using Principal Component Analysis (PCA) with the assumption that changes of stochastic water quality. Factors of human activity and the environment is considered as a random effect that determine changes in water quality (Schoener, 1987). Technical of PCA used in the study of the relationship between ecological phenomena, and its main purpose is synthesizing data variation then interpret multidimensional matrix, meaning that complex ecological data can be synthesized into a simple (Legendre \& Legendre, 1983).

\begin{tabular}{|c|c|c|c|}
\hline No & Parameter & Unit & Move to sub. material and tools \\
\hline 1. & Transparancy & $\mathrm{cm}$ & Secchi disc, directly at the waters \\
\hline 2. & Water temperature & ${ }^{\circ} \mathrm{C}$ & Alcohol thermometer, directly at the waters \\
\hline 3. & $\mathrm{pH}$ & unit & $\mathrm{pH}$ indicator, directly at the waters \\
\hline 4. & Salinity & $\%$ & Refractometer, directly at the waters \\
\hline 6. & Dissolved oxygen & $\mathrm{mg} / \mathrm{L}$ & Using the Winkler titration, directly at the waters \\
\hline 7. & Carbon dioxide & $\mathrm{mg} / \mathrm{L}$ & Titration using EDTA Na, directly at the waters \\
\hline 8. & Nitrate & $\mathrm{mg} / \mathrm{L}$ & Brucine Sulfate, Spectrophotometer, in the lab \\
\hline 9. & Nitrite & $\mathrm{mg} / \mathrm{L}$ & Alfa-nastilamin, Spectrophotometer, in the lab \\
\hline 10. & Total Organic Matters & $\mathrm{mg} / \mathrm{L}$ & Titration using $\mathrm{KMnO}_{4}$, in the lab \\
\hline 11. & Chlorophyll-a & $\mathrm{mg} / \mathrm{m}^{3}$ & method trichromatik, Spectrophotometer, in the lab \\
\hline & Plankton & $\begin{array}{l}\mathrm{cel} / \mathrm{L} \text { atau } \\
\text { Ind } / \mathrm{L}\end{array}$ & $\begin{array}{l}\text { Plankton net with size of mouth of net } 0.30 \mathrm{~m} \text {, mess } \\
\text { size } 60 \mathrm{Im} \text { (for phytoplankton) and } 0.45 \mathrm{~m} ; 150 \mathrm{I} 21 \mathrm{~m} \\
\text { (for zooplankton). }\end{array}$ \\
\hline
\end{tabular}
Calculated "Statistica 8".

Tabel 1. Tools and methods for the observation of the quality of the aquatic environment

\section{Results and Discussion}

\section{Result}

The range water brightness observations in Segara Anakan lagoon was obtained from 25-140 cm, and in Tritih and Muara Dua (30-60 $\mathrm{cm}$ ) (Table 2). The dissolved oxygen content ranges from 1.31-6.02 mg / $\mathrm{L}$ with the lowest dissolved oxygen was obtained in Donan (1.7$3.67 \mathrm{mg} / \mathrm{L}$ ), and was highest in Kleces (3.14$5.37 \mathrm{mg} / \mathrm{L}$ ), while the salinity was between $0.2-13.7 \%$ where the lowest salinity was in Muara Dua (average 0.5 \%o with range 0.3-0.6 $\%$ ), and highest in Plawangan (average $5.7 \%$ with a range of 0.2-13.7\%o).

Nutrient content in Segara Anakan lagoon waters, ie $\mathrm{N}-\mathrm{NO}_{3}, \mathrm{~N}-\mathrm{NH}_{4}$, and $\mathrm{P}-\mathrm{PO}_{4}$ ranged between $0.292-2.871 \mathrm{mg} / \mathrm{L}, 0.021-0.188$ $\mathrm{mg} / \mathrm{L}$, and $0.292-2.871 \mathrm{mg} / \mathrm{L}$ respectively. the lowest nitrate content is Tritih with a range of $0.362-1.050 \mathrm{mg} / \mathrm{L}(0.598 \mathrm{mg} / \mathrm{L})$, and highest in
Muara Dua with range 0.659-2.366 mg/L (1.507 $\mathrm{mg} / \mathrm{L})$. the lowest ammonium content is Plawangan with range $0.190-0.825 \mathrm{mg} / \mathrm{L}(0.477$ $\mathrm{mg} / \mathrm{L}$ ), and highest in Majingklak with range $0.776-2.934 \mathrm{mg} / \mathrm{L}(1.848 \mathrm{mg} / \mathrm{L})$. Send the lowest orthophosphate content in Regel Sapu with range $0.031-0.038 \mathrm{mg} / \mathrm{L}(0.034 \mathrm{mg} / \mathrm{L})$, and highest in Plawangan with range 0.021$0.188 \mathrm{mg} / \mathrm{L}(0.077 \mathrm{mg} / \mathrm{L})$.

The content of chlorophyll-a in the lagoon ranged from $0.41-15.06 \mathrm{mg} / \mathrm{m} 3$, where the highest chlorofill-a content was in Motean ranging from 8.69 to $15.06 \mathrm{mg} / \mathrm{m}^{3}$ with an average of $10.83 \mathrm{mg} / \mathrm{m}^{3}$, and the lowest in Doman with a range of $0.47-2.21 \mathrm{mg} / \mathrm{m}^{3}$ and an average of $1.31 \mathrm{mg} / \mathrm{m}^{3}$. The abundance of zooplankton is $0-3.366$ ind./L, where the highest abundance of zooplankton is in Motean ranging from 664-2.210 ind./L with an average of 1,692 ind./L, and lowest in Doman with 0-814 ind./L and an average of $447 \mathrm{ind} . / \mathrm{L}$. 
Table 2. Average and range of water quality in Segara Anakan Lagoon

\begin{tabular}{|c|c|c|c|c|c|c|c|c|c|c|c|c|}
\hline STATION & Variable & $\begin{array}{r}\text { Transp. } \\
(\mathrm{cm}) \\
\end{array}$ & $\begin{array}{r}\mathrm{pH} \\
\text { (unit) }\end{array}$ & $\begin{array}{r}\mathrm{O} 2 \\
(\mathrm{mg} / \mathrm{L}) \\
\end{array}$ & $\begin{array}{r}\mathrm{NO} 2 \\
(\mathrm{mg} / \mathrm{L})\end{array}$ & $\begin{array}{r}\mathrm{NO3} \\
(\mathrm{mg} / \mathrm{L}) \\
\end{array}$ & $\begin{array}{r}\mathrm{NH} 4 \\
(\mathrm{mg} / \mathrm{L}) \\
\end{array}$ & $\begin{array}{r}\mathrm{PO} 4 \\
(\mathrm{mg} / \mathrm{L}) \\
\end{array}$ & $\begin{array}{r}\text { BOT } \\
(\mathrm{mg} / \mathrm{L})\end{array}$ & $\begin{array}{r}S \\
(\% 0) \\
\end{array}$ & $\begin{array}{r}\mathrm{Chl} \\
(\mathrm{mg} / \mathrm{m} 3)\end{array}$ & $\begin{array}{r}\text { Zoopl. } \\
\text { (ind./L) }\end{array}$ \\
\hline \multicolumn{2}{|c|}{ Standard } & $>45$ & $7-8.8$ & $>5$ & $<0.06$ & $<3$ & $<0.5$ & $<0.015$ & $<10$ & & $1.5-10$ & \\
\hline \multirow[t]{2}{*}{ Tritih } & Average & 47 & 7.3 & 1.93 & 0.025 & 0.598 & 1.555 & 0.043 & 6.58 & 2.2 & 2.39 & 1,664 \\
\hline & Range & $30-60$ & $7.0-7.5$ & $1.83-3.67$ & $0.020-0.033$ & $0.362-1.050$ & $1.093-19.65$ & $0.024-0.069$ & $2.84-8.75$ & $1.1-3.9$ & $0.86-5.43$ & $210-3,366$ \\
\hline \multirow[t]{2}{*}{ Donan } & Average & 67 & 7.7 & 1.77 & 0.020 & 0.861 & 0.741 & 0.041 & 6.47 & 3.3 & 1.31 & 1,500 \\
\hline & Range & $41-90$ & $7.5-8.0$ & $1.70-3.14$ & $0.017-0.023$ & $0.304-1.710$ & $0.219-1.721$ & $0.025-0.072$ & $2.21-9.05$ & $1.6-6.2$ & $0.37-2.11$ & $175-2,184$ \\
\hline \multirow[t]{2}{*}{ K.Sayur } & Average & 59 & 7.9 & 1.80 & 0.021 & 0.831 & 0.604 & 0.047 & 3.83 & 4.0 & 1.61 & 1,895 \\
\hline & Range & $43-85$ & $7.8-8.0$ & $1.73-2.62$ & $0.018-0.025$ & $0.292-1.786$ & $0.289-1.001$ & $0.027-0.073$ & $2.21-6.62$ & $2.0-7.5$ & $0.88-2.65$ & $1,695-2,272$ \\
\hline \multirow[t]{2}{*}{ S.Regel } & Average & 63 & 7.4 & 1.87 & 0.022 & 0.811 & 0.943 & 0.034 & 5.67 & 2.7 & 1.92 & 1,351 \\
\hline & Range & $60-70$ & $7.0-7.6$ & $1.79-3.14$ & $0.018-0.028$ & $0.289-1.575$ & $0.282-1.728$ & $0.031-0.038$ & $2.98-8.02$ & $1.4-4.3$ & $0.88-3.12$ & $680-2,017$ \\
\hline \multirow[t]{2}{*}{ Motean } & Average & 78 & 7.4 & 3.20 & 0.034 & 1.482 & 0.900 & 0.047 & 3.48 & 0.6 & 10.83 & 1,633 \\
\hline & Range & $45-110$ & $7.0-7.9$ & $2.62-5.24$ & $0.017-0.060$ & $0.598-2.871$ & $0.353-1.615$ & $0.044-0.049$ & $2.21-4.50$ & $0.2-1.2$ & $8.69-15.06$ & $821-2,278$ \\
\hline \multirow[t]{2}{*}{ M.Dua } & Average & 47 & 7.5 & 2.97 & 0.018 & 1.507 & & 0.067 & & 0.5 & 9.50 & 1,692 \\
\hline & Range & $30-60$ & 7.5 & $2.65-4.71$ & $0.011-0.024$ & $0.659-2.366$ & $0.684-2.722$ & $0.035-0.114$ & $4.42-8.44$ & $0.3-0.6$ & $3.05-13.17$ & $664-2,210$ \\
\hline \multirow[t]{2}{*}{ Kleces } & Average & 55 & 7.6 & 3.37 & 0.045 & 1.243 & 1.218 & 0.063 & 4.77 & 0.9 & 4.51 & 1,175 \\
\hline & Range & $40-100$ & $7.5-7.6$ & $3.14-5.37$ & $0.013-0.081$ & $0.662-1.909$ & $0.388-2.038$ & $0.024-0.105$ & $3.48-5.74$ & $0.3-1.8$ & $0.88-7.20$ & $87-2,091$ \\
\hline \multirow[t]{2}{*}{ Majingklak } & Average & 45 & 7.3 & 2.70 & 0.042 & 1.438 & 1.848 & 0.048 & 3.39 & 4.6 & 3.12 & 935 \\
\hline & Range & $25-70$ & $7.0-7.5$ & $2.09-6.02$ & $0.014-0.086$ & $1.154-1.669$ & $0.776-2.934$ & $0.032-0.068$ & $2.11-5.69$ & $0.6-12.4$ & $1.29-5.84$ & $402-1,520$ \\
\hline \multirow[t]{2}{*}{ Plawangan } & Average & 77 & 7.6 & 2.53 & 0.023 & 0.748 & 0.477 & 0.077 & 4.92 & 5.7 & 1.43 & 447 \\
\hline & Range & $40-140$ & $7.0-7.8$ & $1.31-5.50$ & $0.011-0.047$ & $0.423-1.317$ & $0.190-0.825$ & $0.021-0.188$ & $3.16-6.93$ & $0.2-13.7$ & $0.41-2.71$ & $0-814$ \\
\hline
\end{tabular}

Table 3. Abundance of juvenile shrimp (ind. $/ 1000 \mathrm{~m}^{2}$ ) in each observation station

\begin{tabular}{|c|c|c|c|c|c|c|c|c|c|c|}
\hline \multicolumn{2}{|r|}{ Names of Shrimp } & \multirow{2}{*}{ Tritih } & \multirow{2}{*}{ Donan } & \multirow{2}{*}{$\begin{array}{l}\text { Kebun } \\
\text { Sayur }\end{array}$} & \multirow{2}{*}{$\begin{array}{l}\text { Sapu } \\
\text { Regel }\end{array}$} & \multirow{2}{*}{ Motean } & \multirow{2}{*}{$\begin{array}{c}\text { Muara } \\
\text { Dua }\end{array}$} & \multirow{2}{*}{ Kleces } & \multirow{2}{*}{ Majingklak } & \multirow{2}{*}{ Plawangan } \\
\hline Local & Scientific & & & & & & & & & \\
\hline Krosok & Metapenaeus elegans & 460 & 11 & 32 & 162 & 2.122 & 205 & 5.324 & 8.723 & 319 \\
\hline Galah & Macrobrachium rosenbergii & 22 & 143 & 0 & 1.004 & 76 & 640 & 868 & 430 & 0 \\
\hline Putih & Fenneropenaeus merguiensis & 22 & 0 & 0 & 0 & 11 & 32 & 0 & 43 & 176 \\
\hline Ronggeng & Harpiosquilla annandalei & 43 & 287 & 0 & 0 & 0 & 0 & 0 & 0 & 0 \\
\hline Rebon & Acetes sp & 26.300 & 618.916 & 0 & 1.147 & 143 & 22 & 151.828 & 0 & 0 \\
\hline Pacet & Penaeus semisulcatus & 0 & 0 & 0 & 0 & 0 & 143 & 0 & 143 & 0 \\
\hline Tepus & Penaeus monodon & 238 & 0 & 0 & 0 & 0 & 0 & 0 & 0 & 0 \\
\hline Jerbung & Fenneropenaeus indicus & 281 & 0 & 0 & 0 & 0 & 0 & 11 & 0 & 0 \\
\hline
\end{tabular}

The abundance of juvenile shrimp in the Segara Anakan lagoon varies considerably between 32-619,357 ind./1000 $\mathrm{m}^{2}$ with an average of 91.099 ind./1000 $\mathrm{m}^{2}$ (Table 3), where the shrimp abundance is heavily dominated by Rebon (Acetes $s p$ ) shrimp with an average of 88,706 ind. $/ 1000 \mathrm{~m}^{2}$, followed by the shrimp Krosok (Metapenaeus elegans), 1,929 ind./1000 $\mathrm{m}^{2}$ and prawn Galah (Macrobrachium rosenbergii), 354 ind. $/ 1000 \mathrm{~m}^{2}$. Other types of shrimp caught in these waters are White shrimp (Fenneropenaeus merguiensis), Ronggeng (Harpiosquilla annandalei), Pacet (Penaeus semisulcatus), Tepus (Penaeus monodon) and Jerbung (Fenneropenaeus indicus).
Principal Component Analysis gives $100 \%$ total variant (8 factors). Figure 2 shows the relationship between the variance for each factor value, and Factor 4 is the turning point of the graph where the total number of cumulative variance values is $77.82 \%$. This suggests that the analysis of this key component provides an optimal picture of the diversity of data from factor 1 to factor 4 , and addition of factor 5 and subsequently lacks a significant picture of the relationship between shrimp adolescents, the environment and observation stations. This condition means that this analysis only able to explain the relationship between juvenile shrimp, environment and observation station equal to $77,82 \%$. 


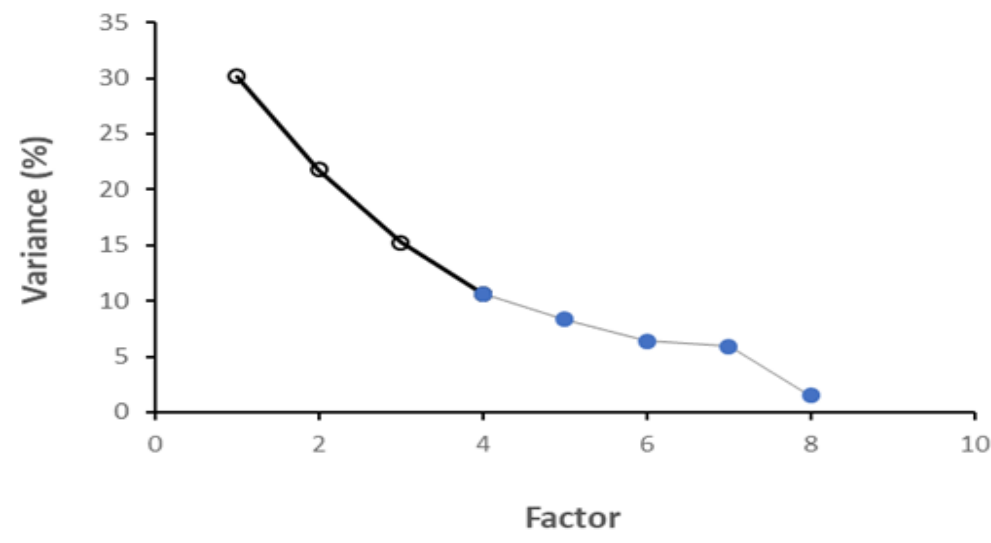

Figure 2. The relationship between the variance for each factor value
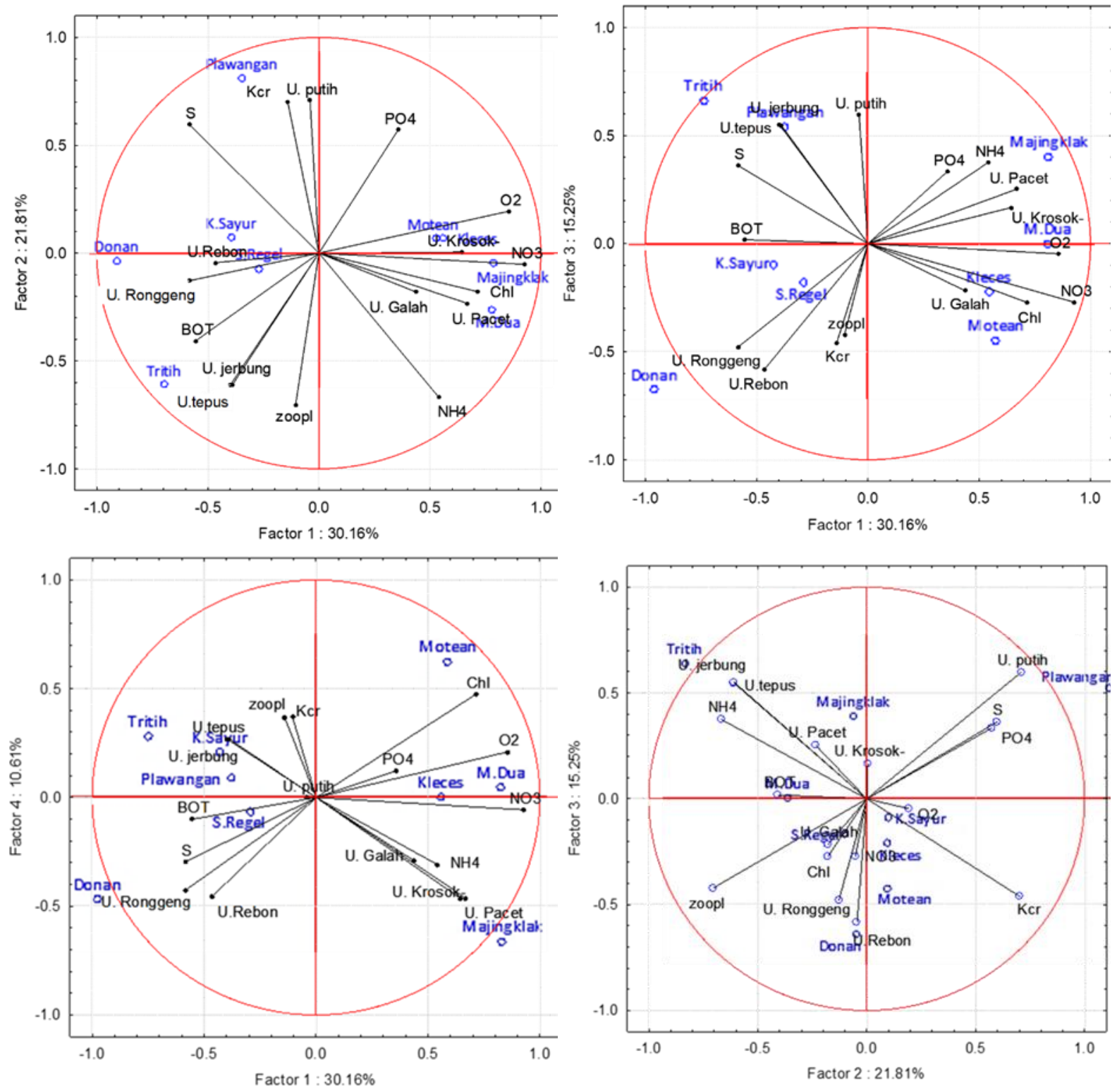

Figure 2. Biplot between variables and correlation based observation stations in the Principal Component Analysis 
Tritih is an observation station in the eastern part of the upper lagoon of Segara Anakan, and in this area is found Fenneropenaeus indicus, and Penaeus monodon, and quite abundantly found Harpiosquilla ammamdalei, Acetes sp and $F$. merguensis. In addition, the station has good forest characteristics, so that it have high the content of Total Organic Material (BOT), salinity and the abundance of zooplankton. Trith also low ocontains of $\mathrm{P}-\mathrm{PO}_{4}, \mathrm{~N}-\mathrm{NO}_{3}, \mathrm{O}_{2}$ and chlorophyll- a (Figure 2). This is due Tritih location is relatively close to the waters of the sea, so that the organic material has not had much time to decompose into nutrients already brought tidal currents toward the sea.

Donan, Kebun sayur and Sapuregel, these three areas have many similarities, these areas have high organic, salinity, abundance of zooplankton and brightness. In addition, this area has low contents of $\mathrm{P}-\mathrm{PO}_{4}, \mathrm{O}_{2}, \mathrm{~N}-\mathrm{NO}_{3}, \mathrm{~N}$ $\mathrm{NH}_{4}$ and chlorophyll-a. When compared with Tritih, the third position of the area is closer to the sea waters, so the process in the nutrient cycle is the same as Tritih. The difference with Tritih, the three areas are juvenile shrimp more dominated by Harpiosquilla ammamdalei and Acetes $s p$.

Motean located in the center of the Segara Anakan lagoon, where this area is found many Metapenaeus elegan, Macrobrachium rosenbergii and Penaeus semisulcatus. It is presumed that this area has unique characteristics, among others: the forest condition of the mangrove is quite good with high content of N-NO3, O2, and chlorophyll-a; $\mathrm{N}-\mathrm{NH} 4$ and $\mathrm{P}-\mathrm{PO} 4$ high enough. In addition, this area has a low content of BOT.

Muara Dua is the middle and upper waters of the lagoon, in this area is found quite abundantly of Macrobrachium rosenbergii and Penaeus semisulcatus. Muara Dua has the characteristics of the waters with good mangrove forest, so this area has high content of $\mathrm{N}-\mathrm{NO}_{3}, \mathrm{O}_{2}$, and chlorophyll- a; N-NH $\mathrm{N}_{4}$ and $\mathrm{P}$ $\mathrm{PO}_{4}$ are high enough. In addition, this area have low content of BOT and salinity.

Kleces and Majingklak are located in the western region of the lagoon, and in this area found many $M$. elegant, and quite abundantly of found of shrimp Macrobrachium rosenbergii, and Penaeus semisulcatus. Characteristics of these waters include good it mangrove forest conditions with high content of $\mathrm{N}-\mathrm{NO}_{3}, \mathrm{O}_{2}$, and chlorophyll-a; $\mathrm{N}-\mathrm{NH}_{4}$ and $\mathrm{P}-\mathrm{PO}_{4}$ are high enough. And the other, Plawangan is area the entrance of sea water in the western lagoon, in this area found many shrimp $F$. merguensis; and quite a lot found of $F$. indicus and Penaeus monodon. Plawangan have the characteristics of the waters, among others, brightness, and high salinity, and high enough BOT content. This area also has a low N-NH4, as well as low content for chlorophyll-a and abundance of zooplankton.

\section{Discussion}

Penaeid shrimp abundance in Segara Anakan Lagoon ranges from 11-8,909 ind. $/ 1000 \mathrm{~m}^{2}$ and an average 2,051 ind. $/ 1000 \mathrm{~m}^{2}$. Abundance of this shrimp is more abundant than penaeid shrimp in the waters of Semarang, where the observations Promonowibowo (2003) stated that the highest abundance of penaeid shrimp in 2001 in Semarang waters reached 256 ind./ha or 25.6 ind. $/ 1000 \mathrm{~m}^{2}$.

Types of shrimp that have high economic value in the Segara Anakan lagoon quite a lot, among others: $P$. semisulcatus, $P$. monodon, Metapenaeus elegans, $M$. affinis, $M$. ensis, $F$ merguensis, $M$. dobsoni and Macrobrachium roserbergii. Abundance of shrimp based on amount in Segara Anakan lagoon is dominated by Metapenaeus elegans (94.04\%), M. ensis (1.58\%), P. semisulcatus (1.55\%), F. merguensis (1.54\%), and $P$. monodon (1.29\%). On the other hand, based on the weight were dominated by Metapenaeus elegans $(90.7 \%), \quad M$. ensis $(4.9 \%), \quad F$. merguensis $(0.3 \%), P$. semisulcatus $(0.2 \%)$ and $P$. monodon (4\%). The conditions were slightly different from the shrimp population in 2000, where Paramenaeopsis coromandelica (25\%), Nematopalaemon tenuipes (18\%), $F$. merguensis (17\%), $M$. ensis $(11 \%)$ and $M$. affinis (7\%) (Dudley, 2000). The results of Sumiono's research (2009) showed that the composition of shrimp caught by apong in Donan village was rebon shrimp (44\%), $M$. elegans $(31 \%)$, dragon shrimp $(19 \%)$ and $F$. merguensis $(6 \%)$. While for the village of Karangtalun the composition of the shrimp catch is $M$. elegans (61\%), F. merguensis (30\%), Parapenaeopsis sculptilis (4\%), Alpheidae (3\%) and Metapenaeopsis sculptilis (2\%) (Sumiono, 2009). Shrimps that have high economic value are slightly different from those in Pemangkat, West Kalimantan, such as Penaeus merguiensis, P. monodon, P. semisulcatus, P. esculentus, P. latisulcatus, Metapenaeus ensis and $M$. endeavouri (Wedjatmiko et al. 2011).

The shrimp habitat varies greatly depending on the type and requirements of life (comfort) for each phase of its life cycle. The larvae are planktonic and drift away from the spawning areas to the bays and estuaries of the river. the postlarvae then migrate to the estuary, which is very rich in nutrients and low salinity. 
These water shrimp grow and sometimes migrate again to the open waters where they mature (Ruas, et al., 2014). Juvenile found coastal waters and lagoon (Anand, et.al., 2014). Adult shrimp are benthic animals that mainly live on the ocean floor. Preferred habitats are soft base types, usually composed of a mixture of mud and sand.

In general, shrimp are caught in large quantities in shallow waters, especially in areas of the river mouth. Penaeid shrimp happy to live in areas where there is a mixing of river water and seawater, because here is widely available food and nutrients needed shrimp. Mangrove forests are areas where seawater and freshwater are mixed, and the forests are able to provide continuous food and serve as a shelter (Pratiwi, 2008).

Shrimps become adults and lay eggs only in marine water habitats. Females are able to spawn 50,000 to 1 million eggs, which will hatch after 24 hours into larvae (nauplius). Nauplius then morphed into the second phase the zoea (plural zoea). Zoea ate wild algae. After a few days morphed into mysis (mysis plural). Mysis eats algae and zooplankton. After three to four days then they metamorphosed the last time entering the pascalarva stage: young shrimp that already possessed the characteristics of an adult animal. The whole process takes about 12 days from the first hatch. In the wild, the postlarvae then migrate to the estuary, which is very rich in nutrients and low salinity (Ruas et al., 1990).

Shrimp Krosok (Metapenaeus elegans), Pacet (Penaeus semisulcatus) and Galah (Macrobrachium rosenbergii) have similarly favored habitats, ie waters with high fertility. These waters are characterized by high levels of chlorophyll-a, N-NO $3, \mathrm{~N}-\mathrm{NH}_{4}$ and $\mathrm{O}_{2}$; and low BOD content. The difference Shrimp Krosok and pacet like waters that have content of $\mathrm{P}$ $\mathrm{PO}_{4}$ and $\mathrm{N}-\mathrm{NH}_{4}$ is high enough to high. While this prawns tend to choose waters with $\mathrm{NO}_{3}$ content and high chlorofill-a content, and low salinity. Thus, the observation stations that are mostly found in the shrimp Krosok, Pacet and Galah are Motean $\left(2,122\right.$ ind./1000 $\mathrm{m}^{2}, 0$ ind./1000 m², 76 ind./1000 m²), Muara Dua (205 ind./1000 $\mathrm{m}^{2}, 143$ ind./1000 m², 640 ind./1000 $\mathrm{m}^{2}$ ), Kleces (5,324 ind./1000 $\mathrm{m}^{2}, 0$ ind./1000 $\mathrm{m}^{2}, 868$ ind./1000 $\left.\mathrm{m}^{2}\right)$, majingklak $(8,723$ ind. $/ 1000 \mathrm{~m}^{2}, 143$ ind./1000 $\mathrm{m}^{2}, 430$ ind./1000 $\mathrm{m}^{2}$ ). In addition, shrimp Krosok widely found in observation stations Plawangan (319 ind./1000 $\mathrm{m}^{2}$ ) and Tritih (460 ind./1000 $\mathrm{m}^{2}$ ).

White Shrimp ( $F$. merguensis) enjoys waters having high salinity, brightness, and $\mathrm{P}$ $\mathrm{PO}_{4}$, as well as low abundance of zooplankton, low enough $\mathrm{N}-\mathrm{NH}_{4}$ and BOT chlorophylls.
Therefore, this white shrimp is found in many observation stations Plawangan (176 ind./1000 $\mathrm{m}^{2}$ ). F. merguiensis has a high adaptability to all basic types of waters, but prefers sandy loam sand water bases (Pratiwi, 2008). Based on his research, the food of some types of Penaeus shrimp such as: $F$. merguiensis is omnivorous, eating what is available in nature. In addition, F. merguiensis mysis levels ate larvae from balanus, copepoda, and polychaeta; and at post larval levels in addition to microorganisms, also ate phytoplankton and green algae (Pratiwi, 2008).

Ronggeng shrimp (Harpiosquilla annandalei), Tepus ( $P$. monodon), Jerbung (Fenneropenaeus indicus) and Rebon (Acetes $s p)$ have many similarities in favorable aquatic habitats, ie waters with high content for BOT and abundance of zooplankton with low for P$\mathrm{PO}_{4}$ and brightness, but Harpiosquilla annandalei and Acetes sp also chose waters with brightness, high BOT content and zooplankton abundance, and high salinity. $P$. monodon and Fenneropenaeus indicus in addition to selecting these waters brightness, BOT content and abundance of zooplankton is also high in waters, and low $\mathrm{N}-\mathrm{NH}_{4}$ content. Thus, Ronggeng, Tepus, Jerbung and Rebon shrimp were found in the Tritih observation station, and found quite a lot in the Kleces observation station (Poernomo, 1968 in Pratiwi, 2008), commonly post larva "tiger prawns (Penaeus monodon) found along the sloping coastline fluctuating tides, and small rivers and sloping bases, mud or small rocky rocks (clam shells). The optimum salinity for growth of tiger shrimp and white shrimp was 10 - 25 ppt (Antony and Harikrishna, 2015, Samocha, et.al, ) and 27 - 31 ppt (Kannan D, et.al, 2015) respectively, while salinity in the study area ranged from 31 to 35 ppt, such conditions inhibit the normal growth of shrimp. This is because tiger prawns can grow better at lower salinity, where the environment allows more energy transformation for the process of meat formation and less energy is used for osmoregulation to maintain fluid pressure balance with the environment (Poernomo, 1978 in Pratiwi, 2008).

Kebun Sayur is the entrance of sea water to the lagoon from the East. This area has the characteristics of deep and wide waters, so cycles the entry of sea water is very smooth. As a result the tidal currents are relatively fast for the eastern lagoon area, thus organic matter has not yet fully decomposed into nutrients already wasted into the sea. The positive impact of the rate of silting this lagoon waters is lower than the western lagoon. 
Muara Dua, Motean, Kleces and Majingklak have very similar water characteristics. The difference is the distance of each observation station to the sea. The furthest position to the sea is Muara Dua station, because the entrance of the sea water circulation is Plawangan Barat. While Plawangan Barat entrance is a very narrow and shallow, so tidal current is relatively slow. These conditions cause the existing organic material to decompose quite a lot into nutrients, such as: $\mathrm{N}-\mathrm{NO}_{3}, \mathrm{~N}-\mathrm{NH}_{4}$ and $\mathrm{P}-\mathrm{PO}_{4}$. This is indirectly causing the Laguna Segara Anakan region of the West is more fertile than the eastern part.

\section{Conclusion}

The abundance of shrimp based on both quantity and weight in the Segara Anakan lagoon is dominated by Metapenaeus elegans $\left(205-8,723\right.$ ind. $\left./ 1000 \mathrm{~m}^{2}\right)$, whereas the abundance of $M$. ensis, $F$ merguensis, $P$. semisulcatus and $P$. monodon are relatively low and having the same habitat, i.e. waters with high fertility and relatively low salinity, relatively high $\mathrm{pH}$. Found in observation station at Motean, Muara Dua, Kleces and Majingklak. Harpiosquilla annandalei $\left(0-330\right.$ ind./1000 $\left.\mathrm{m}^{2}\right)$, $P$. monodon $\left(0-238\right.$ ind. $\left./ 1000 \mathrm{~m}^{2}\right)$, and Acetes sp $\left(0,1-5.196\right.$ ind./1000 $\left.\mathrm{m}^{2}\right)$ where their of characteristic of waters habitat that high contain of BOT and abundance of zooplankton. Thus Harpiosquilla annandalei, P. monodon, and Acetes $s p$ are found in Tritih stations, and are quite commonly found in Kleces stations.

\section{Acknowledgements}

This paper was a contribution of the research activities of the Risk Assessment of Environmental Change Shrimp Resources in Segara Anakan Cilacap District in 2013 Research Institute for Restoration and Conservation of Fish Resources, Jatiluhur. We would like to thank the Head of the Research Institute for Restoration and Conservation of Fish Resources, Jatiluhur his help in conduct of this research. In addition, we would like to thank the entire team of researchers for their cooperation in conducting this research.

\section{References}

American Public Health Association. 2005. Standard methods for the examination of water and waste water. 17th ed. Washington DC, USA. 1193p

Anand, P.S.S; S.M. Pillai; Sujeet Kumar; A. Panigrahi; P. Ravichandran; A.G. Ponniah; and T.K. Ghoskal. 2014. Growth, Ssurvival and lenghth weight relationship of Fenneropenaeus merguiensis at two different stocking densities in low saline zero water exchange brackishwater ponds. Indian Journal of Geo-Marine Science Vol.43 (10), pp. 1955-1966

Antony, Jose and Harikrishna Vungurala. 2015. Effects of Salinity and $\mathrm{Na}+/ \mathrm{K}+$ Ratio on Osmoregulation and Growth Performance of Black Tiger Prawn, Penaeus monodon Fabricius, 1798, Juveniles Reared in Inland Saline Water. Journal of the World Aquaculture Society. Vol. 46, No. 2 doi: 10.1111/jwas.12179

Boyd, E.C., 1990. Water quality in ponds for aquaculture. Birmingham Publishing $\mathrm{Co}$, Birmingham. $482 p$

Davis, G.A. 1955. The Marine and Freshwater Plankton. Michigan State University Press. USA. 562 hal

de Abreu, Daniela Carvalho. 2017. Evaluation of suitable nursery areas for penaeid shrimps in shallow water systems in Southern Mozambique. Doctoral Thesis. Department of Marine Sciences Faculty of Sciences Sweden. University of Gotherburg. $36 \mathrm{p}$

de Freitas, A.J., 2011. The Penaeoidea of South Africa IV- The Family Penaeidae:Genus Penaeus. In: Oceanographic Research Institute Investigational Report No.59., pp. 125.

Dudley, G.R., 2000. Segara Anakan Fisheries Management Plant. Segara Anakan Conservation and Development Project Componen B \& C Consultant Report.

Fulanda, B., Ohtomi, J., Mueni, E., Kimani, E., 2011. Fishery trends, resource use andmanagement system in the Ungwana Bay fishery, Kenya. Ocean Coast. Manage.54, 401-414.

Kannan D, Thirunavukkarasu P, Ashwinikumar ., Shettu N. 2015. Studies on Maturation, Spawning and Hatching Wild of Shrimp Penaeus monodon Fabrics, 1798 Collected from East Coast of India. Journal of Aquaculture \& Marine Biology. Volume 2 Issue 5 
Kunze, H.B, Steven G. Morgan, Kamazima M. Lwiza. 2013. Field test of the behavioral regulation of larval transport. Marine Ecology Progress Series. Vol. 487: 7187. Doi: $10.3354 /$ meps 10283

Legendre, L., P. Legendre 1983. Numerical Ecology. Elsevier Scientigic Publ. Co, New York. $853 p$

Munga, C., Ndegwa, S., Fulanda, B., Manyala, J., Kimani, E., Ohtomi, J., Vanreusel,A., 2012. Bottom shrimp trawling impacts on species distribution and fisherydynamics; Ungwana Bay fishery Kenya before and after the 2006 trawl ban. Fish.Sci. 78, 209-219.Nielsen \& Johnson, 1985

Nielsen, L.A., D.L. Johnson.1985. Fisheries Techniques. American Fisheries Society, Bethesda, Maryland. $468 \mathrm{p}$.

Pramonowibowo, A. Hartoko., A.Ghofar, 2003. Kepadatan Udang Putih (Penaeus merguiensis De Man) di Sekitar Perairan Semarang. Jurnal Pasir Laut, Vol.2, No.2, Januari $2007: 18-29$

Pratiwi, R. 2008. Aspek biologi udang ekonomis penting. Oseana, 33(2): 15-24
Ruas, V. M, Marcos Alaniz Rodrigues, Luiz Felipe Cestari Dumont., Fernando D'Incao. 2014. Habitat selection of the pink shrimp Farfantepenaeus paulensis and the blue crab Callinectes sapidus in an estuary in southern Brazil: influence of salinity and submerged seagrass meadows. Brazilian Crustacean Society, Ribeirão Preto, Brazil. Nauplius 22(2): 113-125, 2014

Schoener, T.W. 1987. Axis oc controversy in community ecology, p. 8-16. In Matthew's, W.J. and D.C. heins (eds.) Community and evaluationary Ecology of North american stream fishes. Univ. of Oklahoma Press.

Sumiono, B. 2009. Kajian Pelestarian Sumberdaya Udang di Perairan Estuarin Segara Anakan, Cilacap. Laporan Akhir Tahun 2009, Kegiatan Program Insentif Bagi Peneliti dan Perekayasa Lembaga Ilmu Pengetahuan Indonesia. Balai Riset Perikanan Laut. 22p

Wedjatmiko, Suprapto., Pratiwi Lestari. 2011. Status Daerah Asuhan Udang Penaeid di Perairan Pemamgkat, Kalimantan Barat. Prosiding Forum Nasional Pemacuan Sumber Daya Ikan III:10p. 